\title{
Understanding Action of Adaptation of Peoples for Floods on Watershed Solo at East Java in Perspective Phenomenology
}

\author{
Ach. Fatchan \\ Professor in Department of Geography - State University of Malang, Indonesia, Email: ach.fatchan.fis@um.ac.id \\ Imam Arifa'illah \\ Department of Geography - State University of Malang, Indonesia, Email: faillah.arif@gmail.com
}

\author{
Doi:10.5901/jesr.2016.v6n2p149
}

\begin{abstract}
Floods that occur in all of the rainy season in the watershed of Solo section downstream, making the population is always adapting. Implies adaptations made in line with the socio-cultural conditions. This study aims to elaborate on the various meanings of the population adaptation measures undertaken in the face of floods in line with social-cultural rationale them. This study used a qualitative approach to the design of phenomenology. The location of this research in the watershed Solo downstream section, namely in Tuban and Lamongan, East Java. Subject or research informants include people who suffered flood and as key informants are local community leaders. Techniques acquire data through observation, interviews, and documentation. Technical analysis of the data using an interactive model. The results showed that the flood disaster solo watershed can lead to: First, the social adaptation in the form of the "taxi boat", rebuilding public facilities and vital cooperation "three-party" government-society-social institutions, joined by close relatives, and helping each other which implies social solidarity. Second, the cultural adaptation in the form of: performing "antru tradition" of building a floating building used jointly by the flood victims, mutual sharing of essential supplies, conduct "autumn mountain" to create a "flood way", do "tahlilan"/"istighosa" or "prayers together". This activity implies that in the face of floods can build a "closeness" with fellow human beings and God. It appears that these research findings differ from previous research findings, which previous research has never reveal deeply that floods can build social solidarity and build closeness to God. In other words, social-cultural changes of adaptation not just "involution" but also "evolution" in line with the knowledge, social-cultural and community relegiusities.
\end{abstract}

Keywords: adaptation, floods, and watershed of Solo

\section{Background}

Solo watershed in the downstream constantly hit by floods in every rainy season. Always flooded areas it covers most in the area of Tuban district and in the district of Lamongan. The region is geographically located in 6 $6^{\circ} 51^{\prime} 54^{\prime \prime}$ until $7^{\circ} 23^{\prime} 6^{\prime \prime}$ South Latitude and $112^{\circ} 4^{\prime} 41^{\prime \prime}$ until $112^{\circ} 33^{\prime} 12^{\prime \prime}$ East Longitude. The region is crossed by the River Solo or local people call it a "Bengawan Solo". The region is located in the lower part, so that during the rainy season the water is often abundant and often lead to floods. According to one of the results showed that the number of occurrences of floods in Solo river basin downstream in the year 2002-2010 a total of 20 times (Suprapto, 2011). It shows that in the period of 8 years flood occurred 20 times. In other words, in each year of at least 2 times a flood occurs. Because of the floods that took place continuously such that community action in adapting the floods also take place simultaneously. Furthermore, it can be presumed that the pattern and adaptation performed constantly evolving in line with the customs and traditions of local communities (Iwan, 2009).

Natural disasters in the region have direct implications for the individual and society. The statement was in line with research findings Suryanti, et-al (2010) who noted that public participation with regard to reducing and avoiding the risk of natural disasters. Participation can be done by increasing the awareness and vigilance of the people to natural disasters there. With that awareness will be more meaningful when linked with the attitude of the people who "care" of the surroundings, which is one of the important components of the individual consciousness of the natural surroundings (Fatchan, et-al, 2009). Against individuals based learning problem-solving experience that there is a process of building an understanding of the various phenomena of life experiences, problems of life, and environmental conditions affected by natural disasters (Toffler, 1974; Cotton, 1990). Furthermore, will be able to improve the understanding, knowledge and 
the meaning of life, increase creativity, and memory mind natural disasters in the region have direct implications for the individual and society. The statement was in line with research findings Suryanti, et-al (2010) who noted that public participation with regard to reducing and avoiding the risk of natural disasters. Participation can be done by increasing the awareness and vigilance of the people to natural disasters there. With that awareness will be more meaningful when linked with the attitude of the people who "care" of the surroundings, which is one of the important components of the individual consciousness of the natural surroundings (Fatchan, et-al, 2009). Against individuals based learning problemsolving experience that there is a process of building up an understanding of the various phenomena of life experiences, problems of life, and environmental conditions affected by natural disasters (Toffler, 1974; Cotton, 1990). Furthermore, will be able to improve the understanding, knowledge and the meaning of life, increase creativity, and memory for each individual mind.

Flood events that take place continuously make individual can implement the appropriate solutions by utilizing a variety of experiences and solving environmental problems. That's because the individuals and communities that are around the disaster site can learn actively and creatively. Atmosphere such individuals tend to be able to build creative thinking, do identivikasi, and solve problems humanist and integrated in accordance with the circumstances of any problems found in the field (Toffler, 1974; Ullich, 1971). Thus, people can respond appropriately and quickly to the issues surrounding natural conditions that run in "meticulous", Geertz (1970) refer to it as the "involution"

The response was the beginning of an adaptation strategy undertaken by a society. In this case, the response generated by the understanding of natural disasters. Understanding in question is public understanding of knowledge that is actualized in attitude or action in the face of disaster. Results of public action in the face of disaster is an adaptation strategies in the form of adjustments made as a result of a disaster or an environmental threat. In other words, adaptation is one way to achieve human survival from a disaster. Where humans have always sought survive a disaster by adapting. This was in line with Darwin's theory of "Survival of the fittest" who noted that all the things in life require adaptation to achieve survival (Fatchan, 2014)

The research seeks to elaborate and reveal the meaning of adaptation actions undertaken residents downstream flow of the Solo River in East Java is required. That's because this area often floods, every year occur at twice the flood. At the time of the flood hundreds and even thousands of homes submerged. The worst flooding occurred in 2007, 2008 and 2012 ago. At that time the flood-affected population reached 7,036 inhabitants and households were flooded as many as 1,277 households. Lately floods in this area is compounded by the distance from the border houses Solo River which average less than 6 meters. In the case rules in Indonesia border river between 6-15 meters (Sumarmi and Amirudin, 2014). Why it happened, the case is clear in the area definitely worth it every year flooded. That sort of thing interesting to understand its meaning as the purpose of this research.

\section{Method}

This study used a qualitative approach with the design of phenomenology. This study seeks to interpret and describe a phenomenon of floods due to overflowing rivers Solo. The understanding is based on the symptoms as it is detailed, holistic, and contextual (Fatchan, 2011; Fatchan, 2013). Data collected by technical documentation, observation, and indepth interviews. Research subjects include residents who suffered flood and community leaders determined snow-ball. By using these techniques is obtained subject of study as many as 9 people. The data obtained were examined by the technical validity of data triangulation, member checking, persistence observation, and audit trail. Furthermore, analyzed simultaneously by using an interactive model as suggested by Miles and Huberman (1992). Eventually found the themes in line with the availability of data, each theme is linked so that results of new proportions.

\section{Result}

One of the solutions that society faced at the time of flooding is adaptation. Various forms of adaptation which is done is the result of a process of adjustment in the face of a changing environment. Adjustments to the environment is done so that people can survive. Shape adaptations made residents in the watershed Solo downstream tend to adjustment measures, engineering, repair, and or changes in the behavior of everyday life. In a review of social culture, adaptations made by the community showed as the following description. 


\subsection{Social Adaptation Measures}

Communities in the watershed Solo downstream part is still largely characterized by society "patembayan". As is characteristic of the Java community in general (Koentjaraningrat, 1996). One proof that it still shows a close relationship with relatives, government, social agencies, and schools or the surrounding community. Of that fact, it can be said that the floods that can strengthen the relationship between the flood victims with relatives, government, social agencies, and the surrounding community. In a rather detailed elaboration of these research findings as presented in Matrix 1.

Matrix 1: Undestanding of Adaptation Measures in Social Life

\begin{tabular}{|c|c|c|}
\hline Informants statement & Themes & Meaning \\
\hline $\begin{array}{l}\text { 1) Mr. Sahari: As the leader of the village, when floods me directly mobilizing } \\
\text { youth, protector unit community, village, community development organizations } \\
\text { to help people. I coordinate and encourage people to help each other and work } \\
\text { together. Village officials and the community together and mutual cooperation to } \\
\text { help the community. }\end{array}$ & $\begin{array}{l}\text { Government and } \\
\text { community leaders } \\
\text { worked together to } \\
\text { deal with floods }\end{array}$ & $\begin{array}{l}\text { Floods can build social } \\
\text { solidarity between the } \\
\text { government, community } \\
\text { leaders, and the peoples flood } \\
\text { victim. }\end{array}$ \\
\hline $\begin{array}{l}\text { 2) Mr Udiyanto: At the time of the flood who work hard are men. Especially for } \\
\text { jobs requiring heavy work, such as making embankments. The work of the } \\
\text { women or mothers help each other cook food. To that end, both (male and } \\
\text { female) working hand in hand with the nearest neighbors. At the time of the } \\
\text { flood actually added a nice neighborly relations. Such a close relationship that } \\
\text { makes us survive, do not despair, and survive together in tackling flooding. }\end{array}$ & $\begin{array}{l}\text {-Solidarity Work } \\
\text { between men and } \\
\text { women } \\
\text {-Solidarity Between } \\
\text { neighbors }\end{array}$ & $\begin{array}{l}\text { Disaster of Bencana Flooding } \\
\text { resulted in strengthening social } \\
\text { solidarity (in the realm of } \\
\text { gender) and an increasingly } \\
\text { powerful neighbor. }\end{array}$ \\
\hline $\begin{array}{l}\text { 3) Mrs. Wiwik: Refuge I did (with family) is to a family in the village Blimbing. } \\
\text { Blimbing exist in coastal areas that are not affected by the floods. However, if } \\
\text { the flood is not how much my family and quite refuge in the river embankment is } \\
\text { located behind my house. }\end{array}$ & $\begin{array}{l}\text {-Solidarity with family } \\
\text {-Mutual cooperation }\end{array}$ & $\begin{array}{l}\text {-Disaster of flooding resulted in } \\
\text { strengthening social solidarity } \\
\text { and mutual help with the family } \\
\text { and neighbors are getting } \\
\text { stronger. }\end{array}$ \\
\hline $\begin{array}{l}\text { 4) Mr. Yanto: At the time of the flooding in this area I use my boat to help others } \\
\text { ("taxi boat"). The fare given any money I serve. That I did because when the } \\
\text { flood of people in need of this kind of boat. Because pity and I have to help } \\
\text { people affected by flooding, the camaraderie with me. }\end{array}$ & $\begin{array}{l}\text { with } \\
\text { transport }\end{array}$ & $\begin{array}{l}\text { Disaster of Flooding resulting } \\
\text { social solidarity by providing } \\
\text { water transport ("taxi boat"). }\end{array}$ \\
\hline $\begin{array}{l}\text { 5) Mr. Surur: I see and feel in the event of flooding shows the relationship } \\
\text { between neighbors becomes tighter. For example, people are very enthusiastic } \\
\text { in various forms of activities to help each other with their neighbors. Community } \\
\text { leaders and residents work together to cope with flooding, such as: fix the dam, } \\
\text { save the school, cattle, and made a public kitchen. }\end{array}$ & $\begin{array}{l}\text { Save social solidarity } \\
\text { and vital public } \\
\text { facilities. }\end{array}$ & $\begin{array}{l}\text {-Disaster of floating resulted } \\
\text { increased social solidarity in } \\
\text { saving public facilities and vital. }\end{array}$ \\
\hline $\begin{array}{l}\text { 6) Mrs Marjumah: My village is common every rainy season flooded. Flood was } \\
\text { coming from the overflow of water from the River of Solo. At the time of floods } \\
\text { occur there is usually a "contribution" in the form of food, medicine, and clean } \\
\text { water. The donation from the neighboring village, private institutions, and } \\
\text { government. }\end{array}$ & \begin{tabular}{|l|} 
Social solidarity of \\
"three party": \\
government, \\
neighbors, and private \\
institutions.
\end{tabular} & $\begin{array}{l}\text { Floods can build social } \\
\text { solidarity "three party" namely } \\
\text { the government, neighbors, } \\
\text { and private institutions. }\end{array}$ \\
\hline $\begin{array}{l}\text { 7) Mrs Aksan: The existence of sufficient help flood embankment. But if the } \\
\text { river water discharge Solo big my house remain flooded. Embankment was } \\
\text { made by the population as "work together" and the cost is partially assisted by } \\
\text { the government. The embankment could also be used as an access road to the } \\
\text { outside of the village in case of more severe flooding. }\end{array}$ & $\begin{array}{l}\text {-Solidaritas With } \\
\text { government } \\
\text {-Mutual cooperation }\end{array}$ & $\begin{array}{l}\text {-Disaster of flooding resulted in } \\
\text { strengthening solidarity and } \\
\text { cooperation with the } \\
\text { government becoming } \\
\text { stronger. }\end{array}$ \\
\hline $\begin{array}{l}\text { 8) Mr. Yahya: At the time of the flooding in this area, the contribution coming } \\
\text { from social institutions, governments, communities and schools. Donated items } \\
\text { usually in the form of blankets, medicines, and clothes. Donated goods were } \\
\text { collected in the Village Hall. During the flood disaster has never been a person } \\
\text { who lost belongings. Various goods originating from donations was never } \\
\text { missing. }\end{array}$ & $\begin{array}{l}\text { Social Solidarity of } \\
\text { "three party": } \\
\text { government, schools, } \\
\text { and private } \\
\text { institutions. }\end{array}$ & $\begin{array}{l}\text {-Disaster Of flooding can build } \\
\text { social solidarity "three party" } \\
\text { namely the government, } \\
\text { schools, and private } \\
\text { institutions. }\end{array}$ \\
\hline $\begin{array}{l}\text { 9) Mrs Siti: To increase revenue and help my fellow flood victims to provide } \\
\text { food by selling food on the river embankment. However, I also happen to have } \\
\text { children who are working outside Java. If there is a flood like this, my son usually } \\
\text { send money to family petrified }\end{array}$ & $\begin{array}{l}\text {-Solidarity with family } \\
\text {-Solidarity with } \\
\text { neighbors }\end{array}$ & $\begin{array}{l}\text {-Disaster of Flooding resulted } \\
\text { in strengthening social } \\
\text { solidarity between family and } \\
\text { neighbors. }\end{array}$ \\
\hline
\end{tabular}

Matrix 1 shows that floods can be understood as an attempt to build social solidarity between the government, community leaders, and people affected by flooding in watersheds Solo. The research findings also indicate that social solidarity is not just awakened from government, community leaders, and communities affected by the floods. 
However, floods can also build social solidarity between genders, in the sense that men and women help each other and be responsible for their respective duties. Flooding in watersheds Solo can strengthen social solidarity and mutual cooperation with relatives and neighbors are stronger. Such solidarity demonstrated by some of the residents providing water transport, ie they provide a boat for a "taxi" to lease voluntarily.

Floods resulted in social solidarity in terms of public facilities and vital save. For example, residents together with local government and social institutions related to rebuild the dam, damaged schools, and rural roads are damaged. In other words, social soslidaritas done "triangle" or "three-party" between the government, neighbors, and related social institutions. Floods resulted in strengthening community solidarity and mutual cooperation of government and become stronger. However, social solidarity also occur in "involution" with family and relatives either in the village or in the outside area. Based on these descriptions can be concluded that the social adaptation in the form of the "taxi boat", rebuilding public facilities and vital cooperation "three-party" government-society-social institutions, joined the family, and mutual help which implies social solidarity. Based on these descriptions can be built a new proposition as follows.

Proposition I: Disaster of floods resulted in the establishment of solidarity "three-party" government, community leaders, and community flood victims. Disaster of floods can build social solidarity between genders. Disaster of floods can strengthen and enhance the social solidarity of society.

\section{Cultural Adaptation or Tradition}

Communities in the watershed Solo downstream are still applying some traditions are derived from a common ancestor. Some of the traditions they did it contain a lot of meaning in life. Some of them carried on that tradition as they flooded. As revealed they are presented in Matrix 2.

Matrix 2: Undestanding of Adaptation Measures in Cultural Life (Tradition)

\begin{tabular}{|c|c|c|}
\hline Informants statement & Themes & Meaning \\
\hline $\begin{array}{l}\text { 1) Mr. Sahari: "Antru" or "Queued" was a floating building made of bamboo } \\
\text { and banana trees are used or where goods, cooking and sleeping. "Antru" } \\
\text { was always floating on the water so as to follow the development of high or } \\
\text { low tide water. If the water rises, "Antru" go up. So that the goods contained in } \\
\text { the above "Antru" not submerged in water. }\end{array}$ & $\begin{array}{l}\text { The tradition of building a } \\
\text { "Queued" during floods }\end{array}$ & $\begin{array}{l}\text { Floods resulted in the creation } \\
\text { of a tradition of making "Antru" } \\
\text { and can increase the sense of } \\
\text { brotherhood }\end{array}$ \\
\hline $\begin{array}{l}\text { 2. Mr Udiyanto: "Alms Earth" is rarely done by the residents affected by the } \\
\text { flooding. "Alms Earth" is the "feast" or "offerings" in places "sacred". However, } \\
\text { now many transferred in the form of "tahlilan" and or "istighosa" to pray } \\
\text { together to Allah the almighty. }\end{array}$ & $\begin{array}{l}\text { The tradition of "alms } \\
\text { earth", "tahlilan", and } \\
\text { "istighosah" } \\
\text { simultaneously }\end{array}$ & $\begin{array}{l}\text { Floods have left people act to } \\
\text { draw closer to our fellow } \\
\text { human beings and to God }\end{array}$ \\
\hline $\begin{array}{l}\text { 3) Mrs. Wiwik: The tradition of "diversion" is done by mutual cooperation. } \\
\text { "Diversion" is a channel for the distribution of emergency water overflow of } \\
\text { water from the River Solo. With the flooding that occurs will be fast receding. }\end{array}$ & $\begin{array}{l}\text { Mutual cooperation make } \\
\text { the "diversion" }\end{array}$ & $\begin{array}{l}\text { The flood disaster resulted in } \\
\text { an increased sense of shared } \\
\text { destiny and responsible joint }\end{array}$ \\
\hline $\begin{array}{l}\text { 4) Mr. Yanto: Time floods like this makes us more villagers do "tahlilan" and } \\
\text { "istighosa" for getting closer to Allah Almighty. However, we also do a "picket" } \\
\text { to oversee flood situation. }\end{array}$ & $\begin{array}{l}\text { Tradition "tahlilan", } \\
\text { "istighosah", and } \\
\text { maintain security together }\end{array}$ & $\begin{array}{l}\text { The flood disaster causing } \\
\text { people to act closer to God } \\
\text { and the increased sense of } \\
\text { togetherness }\end{array}$ \\
\hline $\begin{array}{l}\text { 5) Mr. Surur: During floods the fish in the pond to trickle out, because the } \\
\text { barrier was broken levees and flooded. Therefore, the fish are harvested early } \\
\text { and give rise to a new tradition of "fishing" fish together. Results of fishing can } \\
\text { be sold. So the flood actually bring a blessing for the angler fish. }\end{array}$ & $\begin{array}{l}\text { Damage of "tambak" or } \\
\text { "pond" to bring fish } \\
\text { fishing tradition. }\end{array}$ & $\begin{array}{l}\text { Floods cause human acts } \\
\text { fishing }\end{array}$ \\
\hline $\begin{array}{l}\text { 6) Mrs. Marjumah: Together with the flood victims we give each other basic } \\
\text { commodities and did "tahlilan". The goal in the face of floods we need to get } \\
\text { closer to your fellow man and God }\end{array}$ & $\begin{array}{l}\text { Help each other and pray } \\
\text { together }\end{array}$ & $\begin{array}{l}\text { The flood disaster causing } \\
\text { people to act to help others } \\
\text { and pray together }\end{array}$ \\
\hline $\begin{array}{l}\text { 7) Mrs. Aksan: We help each other flood victims food. To supplement my } \\
\text { income selling food such as cooked rice and fried food. }\end{array}$ & $\begin{array}{l}\text { Mutual aid among flood } \\
\text { victims }\end{array}$ & $\begin{array}{l}\text { The flood disaster causing } \\
\text { people to act to help each } \\
\text { other }\end{array}$ \\
\hline $\begin{array}{l}\text { 8) Mr. Yahya: At the time of the flood we help each other. Examples such as: } \\
\text { helping people, cows, chickens, goats, or other items. Various goods were } \\
\text { collected in the dike that is not flooded. Jointly conduct "autumn mountain" to } \\
\text { create a "flood way", and do "tahlilan". }\end{array}$ & $\begin{array}{l}\text { The tradition of helping } \\
\text { each other, work } \\
\text { together, and pray } \\
\text { together }\end{array}$ & $\begin{array}{l}\text { The flood disaster causing } \\
\text { people to act to help each } \\
\text { other, work together, and pray } \\
\text { together or "tahlilan". }\end{array}$ \\
\hline $\begin{array}{l}\text { 9) Mrs. Siti: We did the "tahlilan" and "istighosah" for getting closer to Allah } \\
\text { the almighty. We also do traditional "earth alms" that the floods subside. }\end{array}$ & $\begin{array}{l}\text { The tradition of "alms } \\
\text { earth" and "tahlilan" or } \\
\text { "istighosah" together }\end{array}$ & $\begin{array}{l}\text { Floods have left people act } \\
\text { "charity" or good deeds and } \\
\text { pray together }\end{array}$ \\
\hline
\end{tabular}


Based on the above matrix can be explained that flooding in watersheds Solo closely related to the tradition of making "Antru". "Antru" or "Queued" is a floating building made by the residents of flood victims are joined together. The building was made of bamboo or banana trees are used to place goods, cooking and sleeping. "Antru" always floating on the water so that its position following the development of high or low tide water. If the water rises, "antru" also rose. So that the goods contained in the above "Antru" is not submerged. The residents were flooded can increase the sense of brotherhood and increasingly sought to draw closer to our fellow human beings and to God.

It also seems that the floods in watersheds Solo resulted in an increased sense of shared destiny and shared responsibility. Interesting that the floods in this area led to the continuity of the tradition of "autumn mountain", made "flood way", and fishing together. The tradition associated with the activity of religious indicated by their actions population increasingly active in conducting a "blessing of the earth" "istighosa", and "tahlilan". The peoples affected by the flooding are increasing their act of "charity", giving, and praying together.

Based on these descriptions can be noted that the cultural adaptation in the form of: a tradition of making "antru" that is to build a floating building used jointly by the flood victims, mutual sharing of basic commodities, do the "fall of the mountain" to create a "flood way", do "tahlilan". Based on these descriptions can be built a new proposition as follows.

Proposition II: Disaster of flooding can enhance human relations and with God. This form of human relations shown in the tradition of making "antru", "autumn mountain", and create a "flood way". The form of a relationship with God is shown in the tradition of "blessing the earth", "istighosa" and "tahlilan." Disaster of flooding further increased action in cooperation, "charity" and pray together.

\section{Discussion}

The flood disaster that occurred in the watershed Solo downstream resulting in increased solidarity are close relatives. The close relatives of residents of flood victims usually visit with the staple food as a sense of brotherhood. That sort of thing has been revealed earlier that in Javanese tradition, individuals are in each a relative, always bound by a strong sense of affinity brother. It was because they felt the same origin and ancestors descendants (Fatchan, 2004). In the event of flooding in watersheds Solo, it formed a division of labor within the family based on the type of work, gender, and severity of a job. If there are some jobs that are considered too heavy, then the neighbors helped. Neighborly interactions that occur at the time of the flood-added well established, it can be seen when people help each other (Fatchan, et-al, 2011). Interaction is woven into everyday life became very good, so a positive influence on the activity of the problems facing floods.

The norms that have been prevailing in the society intervene in floods show more awake. It was shown and demonstrated by the absence of residents who violate the norm when the flood occurred. For example, during the floods there was never a resident incidence of loss of goods or never happen theft of goods. As demonstrated that the various items are placed in the "antru" never lost, even though "antru" was not guarded people. Conditions such formal showed that peoples who experienced flood disasters even more obedient to the values and social norms have been there. As noted Koentjaraningrat (1996) that most of the Java community in everyday life always obey social norms as guidelines that regulate their behavior. Although the process of modernization swept into their lives. However, if modernization is contrary to the norm, the modernization will be rejected (Fatchan; Mustafa; and Soekamto, 2015).

Social solidarity communities affected by flooding in the watershed Solo shows higher. This means that the relationship between them indicates more closely based on the love, friendship, sympathy, mutual respect, and a feeling of satisfaction when helping. The formation of a sense of social solidarity in society has implications for the cohesiveness and attachment of peoples. Thus, it can be said that people have the cooperation and involvement in solving problems faced devastating floods. As has been noted by Johnson (1980) that solidarity refers to a state of the relationship between the individual and / or group based moral feelings and beliefs held together reinforced by a shared emotional experience.

Forms of cooperation such as mutual help solve the problems at the time of the flood. Forms of mutual cooperation, among others: (1) help evacuate, (2) repairing their homes and public facilities, (3) clean up the environment, (4) makes the post evacuation, (5) establish a common kitchen, sharing food, drinks, and clothing, In line with this, Bintarto (1980: 11) reveals that man is essentially dependent in all aspects of life to others. Therefore, man must always strive for as much as possible to maintain good relations with others driven by a spirit of equally the same taste, and always try to the extent possible be in conformity, to do good to one another, and driven by a sense of the same height and the same low (Fatchan, 2004).

In dealing with the floods in Solo river basin downstream part of this it appears that social organizations 
participated. Activities undertaken include helping people make tents or post evacuation, distributes donations from many volunteers, and inform the ebb and flow of the water. To reduce losses and damage to equipment by the floods, people make "antru" and "bangkelan". "Bangkelan" is a place made from fabric width to be used as a container of household items are placed on the roof of the house. Community activities in rescuing a pet when the flood is done in a way to bring pets to the embankment or road.

For peoples who have migrated outside the city family, the family would send help when the flood occurred. The goal is that they can survive amid flood disaster. One form of survival strategy in overcoming the shock and stress of life is by implementing the strategy of the network (Suharno, 2003). The network strategy as establish relationships with existing social environment and associated institutional environment.

Flooding in watersheds Solo can strengthen the relationship between man and man and between man and God. The tradition of the relationship between man and God is expressed in a tradition that is doing the prayers together "tahlilan" and "istighosa". Activities "istighosa" and "tahli" is an indigenous-run society for the purpose of safety. The activity was conducted in the form of a group of about 20-30 people, the students named recitation "bandongan" (Fatchan; Amirudin; and Soekamto, 2015). While relationships are in the shape of social solidarity in the form of mutual assistance activities. For example, in the face of flood them together to make flood way and "antru".

Some cultural adaptation performed the affected population is a tradition of making "antru", mutual sharing of basic commodities, do the "fall of the mountain" to create a "flood way", do "istighosa" and "tahlilan". This activity implies that in the face of floods can establish "closeness" with fellow human beings and with God. It would seem that the findings of this research differs with the findings of Geertz (1970), revealed on socio-cultural changes Javanese society "involution". The findings of this research indicate that changes in society due to floods are not just "involution" but also "evolution" in line with penngetahuan, socio-cultural, and community relegi.

\section{Conclusion}

The flood disaster watershed solo the downstream can lead to: First, the adaptation of social form of the "taxi boat", rebuilding public facilities and vital cooperation "three-party" government-society-social institutions, joined with close relatives, and help each other which implies social solidarity. Second, cultural adaptation in the form of: performing "antru tradition" that makes the building for the purposes terapaung together, sharing basic needs, do the "fall of the mountain" to create a "flood way", do "tahlilan" and "istighosa". This activity implies that in the face of floods can establish "closeness" with fellow human beings and with God. It would seem that these research findings differ from previous research findings, which previous research has never reveal in depth that floods can build social solidarity and build closeness to God. In other words, socio-cultural change in society is not just a "involution" but also "evolution" in line with knowledge, social-cultural, and community relegius.

\section{References}

Bintarto. 1980. Mutual-Help: A characteristic of the Indonesian nation. Yogyakarta, Bina Ilmu

Cotton, Kathleen. 1990. Educating Urban Minority Youth: Research on Effective Practice in School Improvement Research Series, pp136.

Fatchan, Ach. 2004. Theories of Social Change. Surabaya. Publisher Kampusina.

Fatchan, Ach, et-al. 2009. Development and Application of Contextual Learning In School-Based Troubleshooting Disaster Prone Areas In Geography Education. Jakarta. The Ministry of Education and Culture of the Republic of Indonesia. Directorate of Research and Community Service.

Fatchan, Ach, et-al. 2011. Ida Ayu Nyoman Rai: MOTHER NATION Indonesia, Jakarta. Kemang Studio Script.

Fatchan. Ach. 2011. Methods of Qualitative Research. Surabaya. Jenggala Pustaka Utama.

Fatchan. Ach. 2013. Methods Kualitataif: Construction and Phenomenology Approach. Malang. State Univercity of Malang Press.

Fatchan. Ach. 2014. Geography of Plants and Animals. Jogjakarta. Publisher Ombak.

Fatchan, Ach; Mustafa; and Soekamto. Hadi. 2015. Defections "Kiai", "Santri" and Farmers in the New Order and Order Reform in the Islamic Tradition in Rural East Java. Journal of Research on Humanities and Social Sciences. Vol.5, No.10, 2015. ISSN (Paper) ISSN 2224-5766 (Online) 2225-0484 (Online).

Fatchan, Ach; Amirudin, Ach; and Soekamto Hadi. 2015. Education Model "Bandongan" for Farmers Society of Agricultural Skills Training in the Background of Sosioculture "boarding school" in East Java. Mediterranean Journal of Social Sciences. MCSER Publishing, Rome-Italy. Vol 6 No 5 September 2015. ISSN 2039-2117 (online). ISSN 2039-9340 (print).

Geertz, Cliffort. 1970. Agriculture involution: The Process of Ecological Change in Indonesia, Berkeley-Los Angeles, University of California Press. 
Horikoshi, Hiroko. 1987. Kiai and Social Change. Jakarta. P3M.

Iwan, Edi. 2009. The People in the Adaptation Strategy Farmers Anticipate Palm Oil Price Fluctuations. Department of Anthropology, Faculty of Social and Political Sciences, State University of Sumatra

Johnson, Paul Doyle. 1980. Classical Sociological Theory and Modern. Jakarta. Gramedia. Translated by Robert M. Z. Lawang

Koentjaraningrat. 1996. Some of the Principal Social Anthropology. Jakarta. PT. Dian Rakayat

Miles and Huberman. 1992. Qualitative Data Analysis. Jakarta. University of Indonesia (UI-Press)

Scott, James .C. Moral. 1981. Economic upheaval and Subsistence in Southeast Asia. Jakarta. LP3ES

Suharno, Edi. 2003. Articles coping strategies and social functioning, Aloyius Gunata Brata, (Online) pikiranrakyat.com accessed August 25,2014

Sumarmi and Amirudin. 2014. Environmental Education and Conservation-Based Local Wisdom. Yogyakarta. Waves.

Suprapto. 2011. Flood Modelling Statistics Indonesia (Genesis 2002-2010). Disaster Management Journal Volume 2 Number 2, Year 2011, pp 34-43.

Suryanti, E.D., Rahayu, L., and Retnowati, A. 2010. Motivation and Community Participation in Disaster Reduction Efforts Multirisiko Parangtritis Coastal Area "in Multirisiko" Disaster Assessment Coastal Area Parangtritis. Yogyakarta. UGM.

Toffler, Alvine, (Editor). 1974. Learning for Tomorrow. New York. Vintage Book. Unitade State of America.

Ullich, Robert. 1971. Phylosophy of Education. New York. American Book Company. Unitade State of America. 
